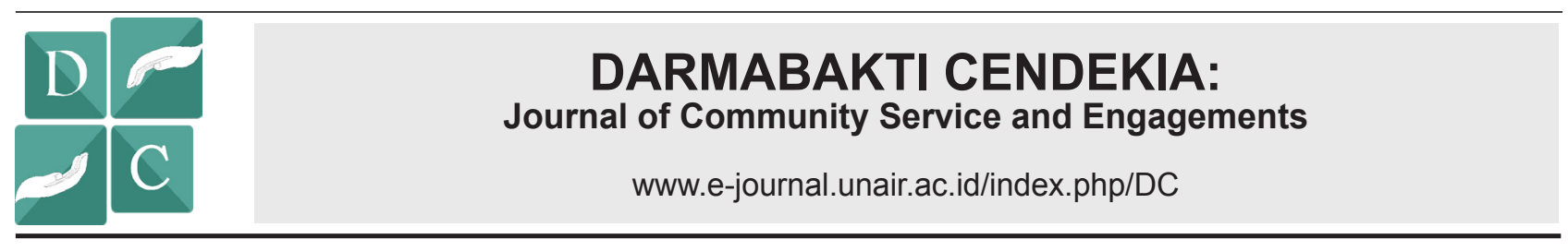

\title{
COMMUNITY EMPOWERMENT IN PINEAPPLE AGROINDUSTRY WASTE UTILIZATION AS AN INGREDIENT OF SNACKS IN SUBANG DISTRICTS
}

\begin{tabular}{l|l} 
PEMBERDAYAAN MASYARAKAT DALAM PEMANFAATAN & Social economy \\
LIMBAH NANAS SEBAGAI BAHAN BAKU PANGAN DAN PRODUK & \\
MAKANAN RINGAN DI SUBANG &
\end{tabular}

Annis Catur Adi ${ }^{*}$, Mahmud Aditya Rifqi ${ }^{1}$, Deandra Ardya Regitasari ${ }^{1}$, Vidya Anggarini Rahmasari ${ }^{1}$, Wizara Salisa ${ }^{1}$, Heni Rachmawati ${ }^{2}$

${ }^{1}$ Faculty of Public Health, Universitas Airlangga, Surabaya-Indonesia

${ }^{2}$ School of Pharmacy, Institut Teknologi Bandung, Bandung-Indonesia

\begin{abstract}
A B S T R A C T
Background:The development of agro-industry in Indonesia remains facing many obstacles. In addition to the environmental wasteproblem, the low ability to process products leads to their low added value, as faced bypineapple agro-industry associationin Barokah Agro Lestari (BAL). This community serviceactivity is important to improvebeneficial and economical value of pineapple agro-industry. Purpose: This activity aims to reduce the environmental burden of pineapple agro-industry by product by implementing technology to giveits added value as well as providing a healthy snack alternative for society. Method: This community service activityis carried out through counseling, training and education related to waste product of pineapple. These activities included the preparation phase, the selection of organic waste of pineapple, bioactive component testing, testing of nutrients and food formulation. Results: The community service program was conducted at PT Karya Masyarakat Mandiri in Subang District and attended by 30 pineapple farmers from Cirangkong village, gathered in Barokah Agro Lestari (BAL). Training was done by administering stages of activity systemically, exposure of the material using visual methods, cooking demonstration for the training activities of processing and product development. Conclusion: Community service activities and training in processing the pineapple stem waste can be a means of empowering local communities. Processing organic waste into food products help improving the community skills and motivation for business development through organic waste treatment.
\end{abstract}

\section{A B S T R A K}

\section{ARTICLE INFO}

Recieved 3 Januari 2020 Accepted 18 Agustus 2020 Online 6 Desember 2020

*Correspondence (Korespondensi): Annis Catur Adi

E-mail: annis_catur@fkm.unair.ac.id

\section{Keywords:}

Organic waste; Pineapple stem; Agro-industry; Community service

\begin{abstract}
Latar belakang: Pengembangan agroindustri di Indonesia selama ini masih mengalami banyak kendala. Selain masalah limbah lingkungan, kemampuan mengolah produk yang masih rendah berdampak memperkecil perolehan nilai tambah komoditas tersebut, sebagaimana dialami oleh agroindustri olahan nanas yang terhimpun dalam komunitas Barokah Agro Lestari (BAL). Pengabdian masyarakat ini penting untuk dilakukan dalam upaya meningkatkan manfaat dan nilai ekonomi hasil samping industri nanas. Tujuan: Kegiatan ini bertujuan untuk mengurangi beban lingkungan limbah organik agroindustri nanas dengan mengaplikasikan teknologi tepat guna untukmeningkatkan nilai tambah produk agroindustri dan menyediakan alternatif makanan ringan yang sehat bagi masyarakat. Metode: Program pengabdian masyarakat ini dilakukan dengan metode penyuluhan, pelatihan dan edukasi. Bentuk kegiatan melalui pelatihan dan sosialisasi terkait limbah nanas berupa batang buah. Kegiatan ini meliputi tahap persiapan, pemilihan limbah organik nanas, pengujian komponen bioaktif, uji zat gizi, dan formulasi pangan. Hasil: Program pengabdian masyarakat ini dilakukan pada komunitas PT. Karya Masyarakat Mandiri di Kabupaten Subang dan dihadiri oleh 30 petani nanas Desa Cirangkong yang terhimpun dalam Barokah Agro Lestari (BAL). Pelatihan dilakukan dengan pemberian tahap-tahap kegiatan secara sistematis, pemaparan materi menggunakan metode visual, demo masak untuk kegiatan pelatihan pengolahan dan pengembangan produk. Kesimpulan: Kegiatan pengabdian masyarakat dan pelatihan pengolahan limbah batang nanas dapat menjadi sarana pemberdayaan masyarakat lokal. Pengolahan limbah organik menjadi produk makanan dapat memberikan ketrampilan dan motivasi untuk pengembangan usaha melalui pengolahan limbah organik.
\end{abstract}

\section{Kata kunci:}

Limbah organik, Batang nanas; Agroindustri; Pengabdian masyarakat 


\section{PENDAHULUAN}

Sumber daya pertanian di Indonesia merupakan salah satu keunggulan dalam pembangunan agroindustri di Indonesia. Peran agroindustri diharapkan dapat menjadi peningkataan dalam segi ekonomi, seperti menciptakan lapangan kerja yang baru (Rusastra et al., 2005). Namun, pengembangan agro industri pertanian di Indonesia masih menghadapi berbagai kendala, seperti masalah limbah lingkungan yang diakibatkan dari kurangnya kemampuan pengolahan produk, baik produk primer dan sekunder. Hal ini dapat menyebabkan penurunan nilai tambah komoditas tersebut.

PT. Karya Masyarakat Mandiri merupakan salah satu agroindustri olahan nanas yang berlokasi di Kabupaten Subang. Pada agro industri ini, masalah beban limbah berupa batang nanas semakin meningkat dengan adanya peningkatan produksi olahan nanas dan penggunaan teknologi pemanfaatan limbah organik nanas yang masih kurang.

Buah nanas (Ananas comosus) merupakan buah yang memiliki banyak mata dan berwarna kuning keemasan. Pohon nanas dapat tumbuh di daerah beriklim tropis, seperti di Indonesia, dengan masa panen 2 sampai 3 kali per tahun. Buah nanas banyak mengandung zat gizi yang bermanfaat bagi tubuh, antara lain vitamin A, kalsium, fosfor, magnesium, zat besi, natrium, kalium, dextrose, serta enzim bromelin (Irfandi, 2005). Enzim merupakan golongan protein yang banyak terdaapt dalam sel hidup (Yasid and Nursanti, 2005). Enzim berfungsi sebagai katalisator reaksi kimia atau mempercepat reaksi kimia tanpa pembentukan produk samping. Aktivitas katalitik enzim bergantung pada integritas struktur sebagai protein. Enzim yang bekerja sebagai katalis dalam reaksi hidrolisis protein disebut enzim proteolitik atau enzim protease (Naiola, 2007; Prahasta, 2009). Bromelin merupakan salah satu enzim proteolitik yang mengkatalisasi penguraian protein menjadi asam amino melalui reaksi hidrolisis (Glider and Hargrove, 2002). Bromelin merupakan kandungan utama dari buah nanas yang bermanfaat dalam bidang farmasi dan makanan.

Kegiatan pengabdian masyarakat ini bertujuan untuk mengurangi beban lingkungan limbah organik agroindustri nanas dengan mengaplikasikan teknologi tepat guna dalam peningkatan nilai tambah produk agroindustri dan menyediakan alternative makanan ringan yang sehat bagi masyarakat.

\section{METODE}

Program pengabdian masyarakat dilakukan dengan menggunakan metode penyuluhan, pelatihan, dan edukasi. Selain itu, kegiatan pengabdian masyarakat merupakan sarana untuk menyalurkan pengetahuan terkait penggunaan dan pengolahan limbah menjadialternatif makanan ringan yang sehat bagi masyarakat sehingga dapat digunakan dan memberikan manfaat untuk masyarakat. Penyuluhan dan pelatihan ini diharapkan dapat menambah pengetahuan tentang cara pengolahan produk makanan ringan yang sehat bagi masyarakat kepada komunitas Barokah Agro Lestari.

Kegiatan ini dilakukan dengan 3 mitra. Mitra pertama yaitu komunitas Barokah Agro Lestari dengan melakukan pendekatan untuk menyiapkan dan memilih limbah organik batang nanas. Mitra kedua yaitu Sekolah Farmasi Institut Teknologi Bandung untuk melakukan pengujian serat dalam limbah organik batang nanas. Mitra ketiga yaitu Laboratorium Gizi Fakultas Kesehatan Masyarakat Universitas Airlangga untuk melakukan uji proksimat, kandungan serat, dan pati resisten, serta melakukan proses pengolahan limbah batang nanas, pengembangan produk makanan, pembuatan kemasan, perhitungan zat gizi dan nilai ekonomi.

Hasil yang diperoleh dari kegiatan ini adalah peningkatan wawasan pengetahun dan keterampilan dalam pengolahan dan penggunaan limbah batang nanas hingga menjadi makanan ringanpada kelompok sasaran. Kegiatan edukasi meliputi sosialisasi dan demo pengolahan limbah batangnanas. Advokasimerupakan pendampingan pada kelompok yang bertujuan untuk menjaga konsistensi kegiatan pemberdayaan pada kelompok sasaran, sehingga sanggup dan mampu melakukan kegiatan pembuatan makanan ringan berbasis produk limbah nanas secara mandiri. Program pengabdian masyarakat tentang pemanfaatan limbah organik nanas dilakukanpada program Kemitraan Masyarakat di Kabupaten Subang, Jawa Barat.

\section{HASIL DAN PEMBAHASAN}

Pelatihan pengolahan limbah organik batang nanas dilakukan pada program Kemitraan Masyarakat di Kabupaten Subang yang terhimpun pada komunitas Barokah Agro Lestari (BAL) beranggotakan 30 petani nanas Desa Cirangkong. BAL merupakan mitra petani nanas yang menjadi dampingan Karya Masyarakat Mandiri Dompet Dhuafa. Rata-rata luas lahan budidaya nanas seluas $0.5 \mathrm{Ha}$ atau total luas lahan nanas paguyuban 
adalah $15 \mathrm{Ha}$.

Respon Mitra Karya Masyarakat Mandiri Dompet Dhuafa selaku pembina dan pendamping petani sangat baik dan penuh antusias karena diberikan solusi terhadap limbah olahan nanas yang selama ini makin banyak dan hanya dimanfaatkan sebagai bahan pupuk. Melalui kegiatan ini, wawasan masyarakat terhadap perubahan limbah menjadi produk yang bernilai ekonomi bahkan memberikan manfaat kesehatan. Pelatihan pemanfaatan teknologi tepat guna yang relatif mudah serta adanya kesamaan visi untuk kesejahteraan, diharapkan menjaga kesinambungan dalam pendampingan berikutnya, termasuk menerima konsultasi inovasi pengembangan yang sudah ditemukan oleh masyarakat petani.

Sedangkan bagi para petani yang tergabung dalam Paguyuban Nanas Masyarakat Subang, pada awalnya kurang tertarik dengan kegiatan ini, namun menjadi makin antusias setelah melihat secara langsung bahwa bonggol nanas dapat diubah menjadi tepung. Masyarakat petani, umumnya lebih mudah menerima sesuatu yang baru jika melihat hasil secara langsung. Minat dan keaktifan petani semakin meningkat, saat hasil tepung bonggol nanas yang dihasilkan dicobakan (disubtitusikan) ke dalam makanan olahan (aneka kue) dan melakukan uji cicip kesukaan (organoleptic) yang hasilnya enak. Keyakinan petani terhadap bahan baku dan snack berbasis tepung bonggol nanas tersebut menjadi makin kuat ketika diberikan pengetahuan tentang kandungan gizi dan bioaktif yang sangat bermanfaat untuk kesehatan.

Tahap pertama kegiatan yang dilakukan pada komunitas Barokah Agro Lestari adalah dengan melakukan persiapan dan pemilihan limbah batang nanas yang layak, memiliki kondisi yang baik, dan berkualitas. Kegiatan selanjutnya adalah pemaparan pelatihan pengolahan batang nanas mentah menjadi produk tepung batang nanas. Kegiatan sosialisasi dilakukan dengan pemaparan materi secara visual menggunakan power point atau slide terkait pengolahan limbah batang nanas. Langkah-langkah pengolahan limbah batang nanas diawali dengan pengupasan dan pencucian batang nanas. Kemudian, dilakukan penggilingan yang akan menghasilkan 2 jenis, yaitu ampas dan cairan. Bagian ampas nanas akan terpisah menjadi 2 , yaitu bagian pati dan serat. Bagian pati dan serat akan dilakukan pengeringan, penggilingan, dan penghalusan. Setelah itu, bagian-bagian tersebut akan menghasilkan tepung pati dan tepung serat (gambar 1).

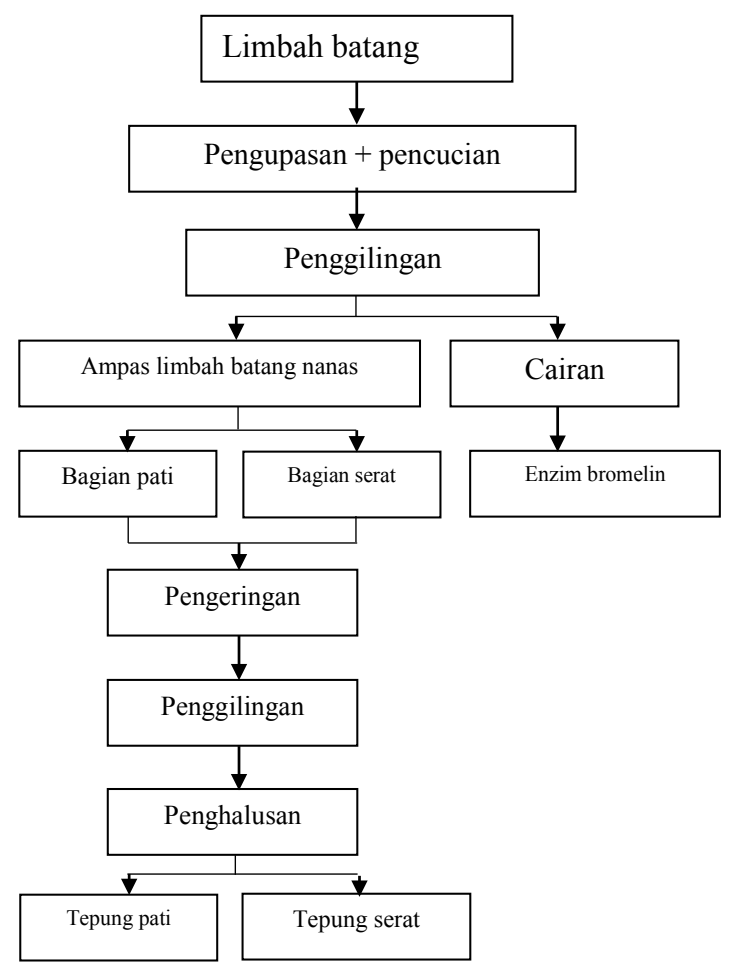

Gambar 1. Diagram alir proses pengolahan limbah batang nanas

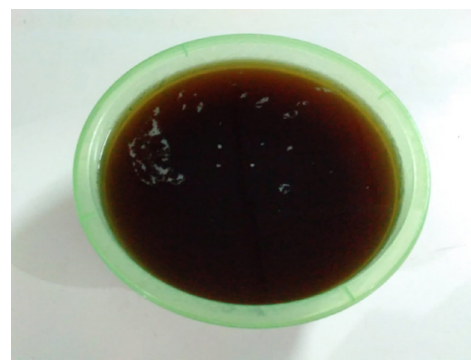

Gambar 2. Cairan hasil pemisahan dari ampas limbah batang nanas

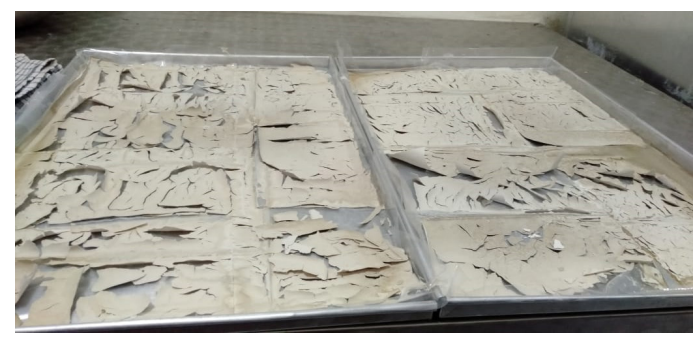

Gambar 3. Pati batang nanas yang dikeringkan dalam oven

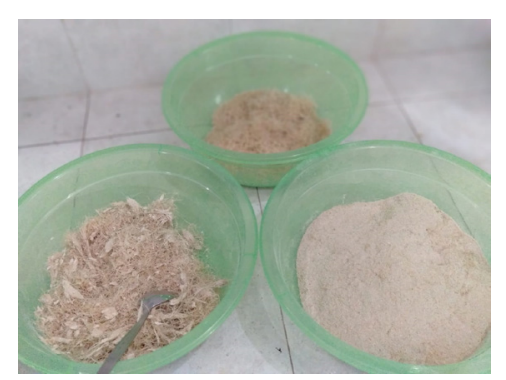

Gambar 4. Batang nanas yang telah dihaluskan menjadi tepung (kanan), tepung bonggol nanas yang setengah halus (atas), dan serat kasar bonggol nanas (kiri) 


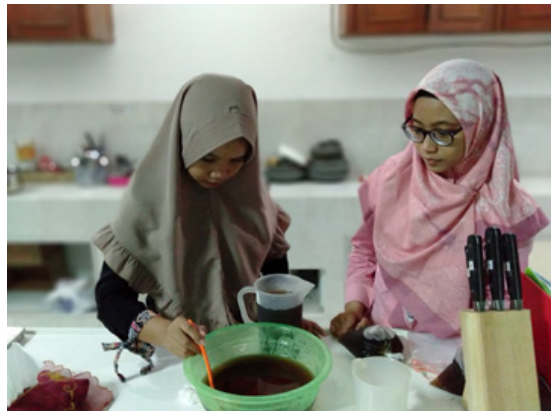

Gambar 5. Demo pengolahan limbah batang Nanas oleh tim

Setelah proses pengolahan limbah organik batang nanas, maka proses akan dilanjutkan dengan tahap pelatihan pengolahan tepung nanas menjadi makanan ringan yang sehat, berupa snack bar. Kegiatan ini menggunakan bentuk kegiatan demo masak.

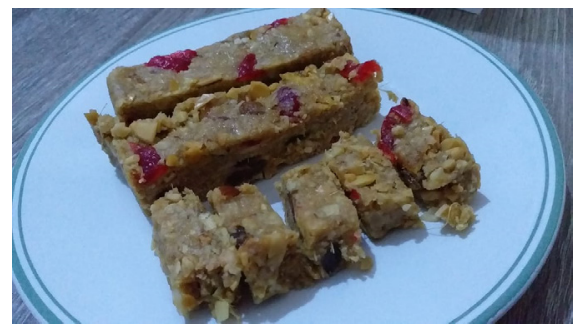

Gambar 6. Snack bar dengan olahan tepung batang nanas

\section{KESIMPULAN DAN SARAN}

Kegiatan pengabdian masyarakat yang dilakukan adalah penyuluhan dan pelatihan pengolahan limbah batang nanas dengan memberdayakan komunitas lokal daerahdan petani nanas. Dampak positif kegiatan ini ditunjukkan pada peningkatan pemahaman dan keterampilan terkait pengolahan limbah batang nanas dan pengolahan makanan ringan. Program ini berpotensi dapat dilanjutkan secara berkesinambungan dan meluas pada masyarakat lain terutama pada area yang ditumbuhi subur pohon nanas. Hasil olahan limbah batang nanas terutama tepung, berpotensi dioalah menjadi aneka makanan ringan, selain snack baryang telah didemokan, memberikan peluang pemberdayaan ekonomi masyarakat Subang serta daerah lainnya.

\section{UCAPAN TERIMA KASIH}

Kegiatan Pengabdian Masyarakat ini didanai oleh Lembaga Pengabdian dan Pengembangan Masyarakat Universitas Airlangga. Penulis juga mengucapkan terima kasih kepada PT. Rumah Inovasi Natura, Surabaya, yang turut berperan melancarkan kegiatan. Selain itu, ucapan terima kasih juga disampaikan kepada pihak mitra, yaitu komunitas Barokah Agro Lestari, Kabupaten Subang, Sekolah Farmasi Institut Teknologi Bandung, dan Laboratorium Gizi Fakultas Kesehatan Masyarakat Universitas Airlangga, yang telah bersedia menjadi mitra dan berperan aktif dalam keberlangsungan kegiatan pengabdian masyarakat ini. Penulis menyatakan tidak ada konflik kepentingan dengan pihak-pihak yang terkait dalam kegiatan pengabdian kepada masyarakat ini.

\section{DAFTAR PUSTAKA}

Glider, W.V., Hargrove, M.S., 2002. Using bromelain in pineapple juice to investigate enzyme function. Proceedings of the 23rd Workshop/ Conference of the Association for Biology Laboratory (ABLE), pp 275-295.

Irfandi. 2005. Karakterisasi Morfologi Lima Populasi Nanas (Ananas comosus (L.) Merr.). Skripsi. Bogor: Institut Pertanian Bogor.

Naiola, E., Widhyastuti, N. 2007. Semi Purifikasi dan Karakterisasi Enzim Protease Bacillus sp. Berk. Penelitian Hayati Vol. 13. Pp. 51-56.

Prahasta, A. 2009. Agribisnis Nanas. Bandung: Pustaka Grafika.

Rusastra, I.W., Noekman, K. M., Supriyati, Suryani, E., Elizabeth, R., Suryadi, M. 2005. Analisis Ekonomi Ketenagakerjaan Sektor Pertanian dan Pedesaan di Indonesia. Laporan penelitian. Bogor: Pusat Penelitian Agro Ekonomi Pertanian.

Yasid, E., Nursanti, L. 2005. Penuntun Praktikum Biokimia untuk Mahasiswa Analis. Yogyakarta: Penerbit Andi. 